\title{
LACK OF PRSS1 AND SPINK1 POLYMORPHISMS IN SERBIAN ACUTE PANCREATITIS PATIENTS
}

\author{
Ivan Radosavljevic, Andjela Milojevic, Jelena Miljkovic, Ana Divjak, Ivana Jelic, Viktorija Artinovic, Marko Spasic, \\ Bojan Stojanovic, Predrag Canovic, Slobodan Jankovic, and Natasa Djordjevic \\ Faculty of Medical Sciences, University of Kragujevac, Serbia
}

\section{ODSUSTVO PRSS1 I SPINK1 POLIMORFIZMA KOD SRPSKIH PACIJENATA OBOLELIH OD AKUTNOG PANKREATITISA}

\author{
Ivan Radosavljević, Anđela Milojević, Jelena Miljković, Ana Divjak, Ivana Jelić, Viktorija Artinović, Marko Spasić, \\ Bojan Stojanović, Predrag Čanović, Slobodan Janković i Nataša Đorđević \\ Fakultet medicinskih nauka, Univerzitet u Kragujevcu, Srbija
}

\begin{abstract}
Acute pancreatitis represents an acute nonbacterial inflammation of the pancreas caused by a premature and ectopic activation of pancreatic digestive enzymes. Two of the most important genes in pancreatic autodigestion, PRSS1 and SPINK1, were implicated in the earliest discoveries of the genetic background of pancreatitis. However, the distribution of their variations displays interethnic variability, which could significantly affect the magnitude of their proposed effects on this disease worldwide. The aim of the present study was to investigate the distribution of the most important functional variations of PRSS1 (86A>T and 365G>A) and SPINK1 $(101 A>G)$, and their influence on the clinical course of acute pancreatitis in Serbian patients. The study enrolled 81 subjects, the severity of disease course was determined using the Atlanta Classification system, and the genotyping was conducted using a PCR-RFLP method. PRSS1 86A>T and $365 G>A$ SNPs were not observed in the study population, while SPINK1 101A>G was present with the frequency of $0.62 \%$ (95\% CI: $0.00,3.83 \%$ ). Due to extremely low frequencies or absences of examined variations, the proposed effect of these SNPs on the severity of acute pancreatitis could not be confirmed. The results do not support routine genotyping of either PRSS1 or SPINK1 in Serbs.
\end{abstract}

Keywords: PRSS1, SPINK1, genetic polymorphism, acute pancreatitis, Serbian

\section{SAŽETAK}

Akutni pankreatitis predstavlja akutno neinfektivno zapaljenje pankreasa, prouzrokovano prevremenom i ektopičnom aktivacijom pankreasnih digestivnih enzima. Enzimi PRSS1 and SPINK1, koji igraju neke od najvažnijih uloga u pankreasnoj autodigestiji, prvi su otkriveni faktori genetske predispozicije za nastanak pankreatitisa. Ipak, zastupljenost njihovih genetskih varijacija varira u zavisnosti od etničke pripadnosti, što u velikoj meri utiče na značaj njihovog učešća u ovoj bolesti širom sveta. Cilj ove studije bio je da ispita distribuciju najznačajnijih funkcionalnih varijacija gena PRSS1 (86A>T i 365G>A) i SPINK1 (101A>G), kao $i$ njihov uticaj na kliničku sliku bolesti, kod Srba obolelih od akutnog pankreatitisa. Istraživanje je uključilo 81 ispitanika, težina bolesti određivana je uz korišćenje Atlanta klasifikacionog sistema, a genotipizacija je sprovedena pomoću PCR-RFLP metode. PRSS1 polimorfizmi 86A>T i 365G>A SNPs nisu detektovani u ispitivanoj populaciji, dok je učestalost SPINK1 101A>G varijacije iznosila 0,62\% (95\% IP: 0,00; 3,83\%). Obzirom na ekstremno nisku učestalost ili potpuno odsustvo ispitivanih varijacija, njihov efekat na težinu $i$ tok akutnog pankreatitisa nije mogao biti potvrden. Rezultati istraživanja ne preporučuju rutinsku genotipizaciju PRSS1 i SPINK1 kod Srba.

Ključne reči: PRSS1, SPINK1, genetski polimorfizam, akutni pankreatitis, srpski

\section{ABBREVIATIONS}

PRSS1 - cationic trypsinogen (protease serine type 1); SPINK1 - pancreatic secretory trypsin inhibitor (serine protease inhibitor Kazal type 1); SNP - Single nucleotide polymorphism;
EDTA - ethylene diamine tetracetic acid;

PCR - Polymerase chain reaction;

PCR-RFLP - Polymerase chain reaction-restriction fragment length polymorphism 


\section{INTRODUCTION}

Acute pancreatitis is an acute nonbacterial inflammation of the pancreas caused by a premature and ectopic activation of pancreatic digestive enzymes (1-3). In most cases, the disease is mild and self-limiting. However, more than $25 \%$ of patients develop a severe form of acute pancreatitis. Of those, more than half die, often during the first week after admission, due to local complications, haemodynamic instability and/or multiple organ failure $(2,4-6)$. As the treatment outcome highly depends on both the type and timing of the management, early differentiation between mild and severe acute pancreatitis has proven to be of the utmost clinical importance (6). Ultimately, identification of biomarkers for severe disease course upon the very first admission would be extremely beneficial for improving the chance of a good response to therapy.

Genetics, and environmental factors significantly contribute to the onset, severity and outcome of acute pancreatitis (7-9). Numerous zymogens and inflammatory mediators that regulate the process are polymorphic, and their genetic variations among pancreatitis patients have often been associated with a more severe clinical course and a worse prognosis $(3,10-12)$. Two of the most important role players in pancreatic autodigestion, cationic trypsinogen (protease serine type 1, PRSS1) and pancreatic secretory trypsin inhibitor (PSTI, serine protease inhibitor Kazal type 1, SPINK1), were implicated in the earliest discoveries of the genetic background of pancreatitis $(13,14)$. PRSS1 is the major isoform of trypsinogen, the most important pancreatic zymogen, which is catalysed into trypsin by enterokinase or other trypsin molecules $(3,9)$. The PRSS1 coding gene is polymorphic, and the most significant variations include $365 \mathrm{G}>\mathrm{A}$ and $86 \mathrm{~A}>\mathrm{T}$ single nucleotide polymorphisms (SNPs) that are linked to a malfunction of the normal process of trypsin inactivation by trypsin-like molecules and other inhibitors of its enzymatic activity $(7-9,15)$. In contrast, SPINK1 represents the first line of defence against premature trypsinogen activation as it inhibits trypsin activity within pancreatic acinar cells $(3,7,9,16)$. SPINK1 is also encoded by a polymorphic gene, and its most important variation $101 \mathrm{~A}>\mathrm{G}$ has been associated with the increased risk of acute pancreatitis, especially in the presence of other significant genetic or environmental factors $(7,9,16)$.

Previous research has established that both PRSS1 and SPINK1 polymorphisms have the potential to modulate the clinical presentation and prognosis of pancreatitis. Moreover, the distribution of these variations differs among populations (17-22), and this interethnic variability could significantly affect the magnitude of their proposed role in pancreatitis worldwide. The aim of the present study was to investigate the distribution of the most important functional PRSS1 and SPINK1 variations and their influence on the clinical course of acute pancreatitis Serbian patients.

\section{MATERIALS AND METHODS}

\section{Study subjects}

The study enrolled 81 Serbian patients with diagnosed acute pancreatitis, who were admitted to the Intensive Care Unit of the Clinical Centre Kragujevac in Serbia, from November 2011 until February 2014. Severity of disease course was determined using the Atlanta Classification system (23). The study was conducted in accordance with the Declaration of Helsinki and its subsequent revisions, and all patients or their legal representatives gave written informed consent. The approval for conducting the study was obtained from the ethics committee at the Clinical Centre Kragujevac.

\section{Genotyping}

Genomic DNA was isolated from EDTA blood samples using the QIAamp DNA Mini Kit (QIAGEN GmbH, Hilden, Germany). DNA concentration was determined by a Qubit ${ }^{\mathrm{m}}$ dsDNA HS Assay Kit on the Qubit ${ }^{\circ}$ 2.0 Fluorometer (Invitrogen, Carlsbad, CA). All PCR reactions were performed on the Techne Genius PCR Thermal Cycler (Techne, Cambridge, UK). The PCR amplicons and restriction fragments were detected by gel electrophoresis on a $2.4 \%$ agarose gel stained with Sybr ${ }^{\circ}$ safe DNA gel stain (Invitrogen, Carlsbad, CA).

A polymerase chain reaction-restriction fragment length polymorphism (PCR-RFLP) method was used for genotyping PRSS1 variation 365G>A (rs111033565, $\mathrm{R} 122 \mathrm{H})$ and was previously reported by Masamune et al. (24). Briefly, the PCR reaction was performed in a $16 \mu \mathrm{l}$ mixture of $0.2 \mu \mathrm{M}$ dNTP Mix (Thermo Scientific, Waltham, MA), $2.5 \mathrm{mM} \mathrm{MgCl} 2,0.2 \mu \mathrm{l}$ of primers 5'- TGACCCACATCCCTCTGCTG -3' and 5'- TCTCCATTTGTCCTGTCTCT -3' (Invitrogen, Carlsbad, CA), $0.5 \mathrm{U}$ of DreamTaqDNA Polymerase (Thermo Scientific, Waltham, MA), and $20 \mathrm{ng}$ of DNA in 1X PCR buffer (Qiagen, Hilden, Germany). The conditions included an initial denaturation at $95^{\circ} \mathrm{C}$ for $5 \mathrm{~min}$; 30 cycles of denaturation at $95^{\circ} \mathrm{C}$ for $1 \mathrm{~min}$, annealing at $64^{\circ} \mathrm{C}$ for $1 \mathrm{~min}$, extension at $72{ }^{\circ} \mathrm{C}$ for $1 \mathrm{~min}$; and a final extension at $72{ }^{\circ} \mathrm{C}$ for $5 \mathrm{~min}$. PCR generated $615 \mathrm{bp}$ long amplicons, which remained uncut by the AflIII (NEB, Hertfordshire, UK) restriction enzyme in the presence of the $365 \mathrm{G}$ allele. Variant allele 365A was, on the other hand, digested to $323 \mathrm{bp}$ and 292 bp fragments.

PRSS1 SNP 86A $>\mathrm{T}$ (rs111033566, N29I) was detected using PCR-RFLP as described by Mora et al. (25). In short, PCR was performed in a $16 \mu$ reaction mixture, containing $20 \mathrm{ng}$ of DNA, $0.2 \mu \mathrm{M}$ dNTP Mix (Thermo Scientific, Waltham, MA), $1.5 \mathrm{mM} \mathrm{MgCl}, 0.2 \mu \mathrm{l}$ of primers 5'-CGCCACCCCTAACATGCTAT-3' and 5'-CTCTCCCAGGCAGACTGGCC-3' (Invitrogen, Carlsbad, CA) and $0.5 \mathrm{U}$ of DreamTaqDNA Polymerase (Thermo Scientific, Waltham, MA) in a 1X PCR buffer (Qiagen, Hilden, Germany). The PCR conditions were an initial denaturation at $95{ }^{\circ} \mathrm{C}$ for $5 \mathrm{~min} ; 40$ cycles of denaturation at 95 
${ }^{\circ} \mathrm{C}$ for $30 \mathrm{sec}$, annealing at $64{ }^{\circ} \mathrm{C}$ for $30 \mathrm{sec}$, extension at $72{ }^{\circ} \mathrm{C}$ for $30 \mathrm{sec}$; and final extension at $72{ }^{\circ} \mathrm{C}$ for $5 \mathrm{~min}$. The amplification resulted in 266 bp long PCR products, which were then exposed to the restriction enzyme TaaI (Thermo Scientific, Waltham, MA). Digestion of the wild type allele yielded three fragments of $102 \mathrm{bp}, 79 \mathrm{bp}$ and $85 \mathrm{bp}$, while variant $86 \mathrm{~T}$ allele was cut to $181 \mathrm{bp}$ and 85 bp fragments.

Genotyping for SPINK1 101A>G (rs17107315, N34S) was conducted using the PCR-RFLP method according to Gomez-Lira et al. (16). Briefly, an 138 bp SPINK1 region was amplified in a total PCR mixture amount of $18 \mu \mathrm{l}$, including $20 \mathrm{ng}$ of DNA, $0.2 \mu \mathrm{M}$ dNTP Mix (Thermo Scientific, Waltham, MA), $1.5 \mathrm{mM} \mathrm{MgCl2}$, $0.2 \mu \mathrm{l}$ of primers 5'-CAATCACAGTTATTCCCCAG-3' and 5'-TGGTGCATCCATTAAGTGCA-3' (Invitrogen, Carlsbad, CA) and 0.5 U of DreamTaqDNA Polymerase (Thermo Scientific, Waltham, MA) in a $1 \mathrm{X}$ PCR buffer (Qiagen, Hilden, Germany). The reaction mixture was submitted to an initial denaturation at $95^{\circ} \mathrm{C}$ for $5 \mathrm{~min}$; 35 cycles of denaturation at $94^{\circ} \mathrm{C}$ for $30 \mathrm{sec}$, annealing at $54{ }^{\circ} \mathrm{C}$ for $30 \mathrm{sec}$, extension at $72{ }^{\circ} \mathrm{C}$ for $1 \mathrm{~min}$; and final extension at $72{ }^{\circ} \mathrm{C}$ for $5 \mathrm{~min}$. PCR products underwent restriction digest by the Bsp1286I enzyme (Thermo Scientific, Waltham, MA), which cut only variant allele to $122 \mathrm{bp}$ and $16 \mathrm{bp}$ fragments, while wild type 101A remained uncut.

\section{Statistical analysis}

Genotype data were presented as haplotype and genotype frequencies, and the 95\% confidence interval calculations were calculated according to the modified Wald method.

\section{RESULTS}

The study population was comprised of 54 men and 27 women aged between 23 and 86 (median age 59 years). Of them, 35 and 46 were classified as mild and severe acute pancreatitis patients, respectively. Among the 81 examined Serbian acute pancreatitis patients, PRSS1 86A $>$ T and 365G $>$ A SNPs were not observed. SPINK1 variant $101 \mathrm{G}$ was present in the study population with a frequency of $0.62 \%$ (95\% CI: $0.00,3.83 \%)$, as only one study subject was a heterozygous carrier. This patient was a 48-years old overweight male (BMI: $29.3 \mathrm{~kg} / \mathrm{m}^{2}$ ), cigarette smoker (20 cigarettes per day) and long-term (10 years) alcohol consumer (3 alcohol drinks per day) with confirmed gallstone disease, who developed a severe form of acute necrotizing pancreatitis with pancreatic pseudocyst. This was his first attack of acute pancreatitis, and no one in his family suffered from this condition before. The patient was treated with analgesics, fluid and nutritional support and antibiotics and antisecretory drugs and was discharged from the hospital fully recovered.

\section{DISCUSSION}

In the present study, we investigated the distribution of the important functional PRSS1 and SPINK1 polymorphisms among Serbian patients diagnosed with mild or severe acute pancreatitis. To our best knowledge, this is the first study in Serbs on the genetic background of acute pancreatitis. Due to extremely low frequencies or the absence of examined variations, the proposed effect on severity of disease course could not be observed.

PRSS1 is the most abundant pancreatic precursor of trypsin, which becomes active after cleavage of a short, exposed peptide chain named trypsinogen activation peptide (26). The gene encoding PRSS1 is located on long arm of chromosome 7 (7q35), spans approximately $3.6 \mathrm{~kb}$ and comprises 5 exons (27). This gene is highly polymorphic, with more than 30 genetic variations reported so far (www. uni-leipzig.de/pancreasmutation). The first described and the best studied are exonic gain-of-function $\mathrm{G}>\mathrm{A}$ and $\mathrm{A}>\mathrm{T}$ substitutions at positions 365 and 86, respectively $(13,28)$. The former leads to an arginine $(\mathrm{R})$ to histidine $(\mathrm{H})$ replacement at codon 122 of the trypsinogen molecule (13). Because $122 \mathrm{R}$ represents the initial site for trypsin autohydrolysis, $\mathrm{R} 122 \mathrm{H}$ renders trypsin resistant to inhibition and available for excessive activation of zymogens within the pancreas $(29,30)$. On the other hand, $86 \mathrm{~A}>\mathrm{T}$ results in amino acid substitution of asparagine (N) with isoleucine (I) at codon 29 (28). This causes an alteration of the secondary structure of the protein, making 122R site inaccessible for trypsin attack, thus providing the same autolysis-preventing effect as R122H (29-31). Trypsinogen activation should take place only after leaving the pancreas, as the creation of trypsin inside acinar cells would lead to pancreatic autodigestion and inflammation $(1-3,11)$. Previous studies found that pancreatitis develops in approximately $80 \%$ of carriers of the $365 \mathrm{G}>\mathrm{A}$ or $86 \mathrm{~A}>\mathrm{T}$ variation. Thus PRSS1 is considered a causative gene in hereditary pancreatitis $(8,29,31,32)$. However, in spite of the common underlying mechanism, 365G $>\mathrm{A}$ and $86 \mathrm{~A}>\mathrm{T}$ result in a different clinical course of the disease, as patients with the N29I substitution generally have milder disease symptoms with a later age of onset $(33,34)$.

Hereditary pancreatitis is characterized by multiple attacks of acute pancreatic inflammation that often progresses to a chronic form $(8,29,31,32)$, confirming that all types of pancreatitis share a common pathogenetic mechanism $(7,8,11,32,35,36)$. Therefore, it could be expected that PRSS1 variations contribute, at least to a certain extent, to the development and severity of sporadic pancreatitis as well. However, in cases without a strong family history, the roles of PRSS1 365G $>$ A and 86A $>$ T are less understood. In addition, there are discrepancies in observations among different populations, implying interethnic differences in PRSS1 variation frequency (21, $25,31,37-45)$. In the present study, genotyping of Serbian acute pancreatitis patients of both mild and severe clinical course revealed no carriers of either $365 \mathrm{G}>\mathrm{A}$ or 
$86 \mathrm{~A}>\mathrm{T}$ variations in the PRSS1 gene. This corresponds well to the previous data obtained from Caucasians diagnosed with non-hereditary forms of pancreatitis $(8,17$, $22,24,25,32,37,39,40,43,46)$, arguing against genetic testing of PRSS1 in acute pancreatitis cases in our population (35). Most likely, environmental or other genetic risk and modifying factors are involved in pathogenesis and affect the severity of this disease in Serbs.

SPINK1 is an acute phase protein, synthesized in the acinar cells of the pancreas together with PRSS1. Being a strong protease inhibitor, its main role is to prevent premature trypsinogen activation and pancreatic autodigestion by creating a covalent bond between its lysine residue at position 41 and the catalytic serine residue of trypsin (12, 31, 47-50). The SPINK1 coding gene is localized on chromosome 5 (5q32), and it consists of 4 exons spanning a region of approximately $7.5 \mathrm{~kb}(51)$. There are almost 40 genetic variations of SPINK1 identified so far (www.unileipzig.de/pancreasmutation), with an A to G substitution at position 101 among the first and best described in connection with pancreatitis $(14,47)$. This is an exonic missense variation that leads to the replacement of asparagine $(\mathrm{N})$ with serine $(\mathrm{S})$ at codon 34 and was discovered in a pancreatitis family without PRSS1 mutations (47). It has been suggested that N34S renders SPINK1 incapable of inhibiting trypsinogen by causing the conformational changes within the substrate/inhibitor binding segment of the protein $(14,31)$. Because control of trypsin activity largely depends on SPINK1, it has been speculated that 101A>G, as a loss-of-function variation, could be at least be partly responsible for inflammation of the pancreas (47). However, investigations yielded contradictory results (52). While some of the studies observed no association between this variation and the disease risk or severity $(22,47,53,54)$, others reported SPINK1 101A $>\mathrm{G}$ as either a cause $(14,24)$ or a cofactor $(16,17,31,32,37,39,55)$ in pancreatitis development.

In the present study, only one out of 81 Serbian acute pancreatitis patients was found to be a carrier of SPINK1 $101 \mathrm{~A}>\mathrm{G}$. The observed frequency belongs to the lower end of the wide span of previously published data for sporadic idiopathic pancreatitis cases among different populations. These include Brazilian (22), Chinese (44), Japanese (24, $56)$, French $(38,43,47)$, German $(14,57)$, Italian $(16,40)$, Romanian (58), British (53), Spanish (25), Danish (41), American (31), Polish (42), or Indian (37), presenting with 0.0\%, 0.0\%, 0.0-3.1\%, 0.0-10.3\%, 0.5-23.0\%, 2.7-9.4\%, 5.0\%, $18.0 \%, 18.8 \%, 19.5 \%, 25.0 \%, 28.6 \%$, and $32.5 \%$ of $101 \mathrm{~A}>\mathrm{G}$ carriers, respectively. This overall discrepancy could be a consequence of a different composition of patients involved in the studies, i.e., different forms and aetiologies of pancreatitis cases described $(38,59)$. However, regardless of the risk factors and clinical presentations, all types of pancreatitis have the same pathogenesis, showing premature and uninhibited pancreatic zymogens activation (7, $8,11,32,35,36)$. Therefore, it is more probable that the difference in observed frequencies demonstrates an inter- ethnic variability in terms of SPINK1 101A > G distribution $(42,44)$, which could explain earlier conflicting findings on its role in pancreatitis initiation and severity. As for the Serbian SPINK1 101A>G carrier presented here, the acute attack of the disease in his case was severe. However, he displayed several known pancreatitis risk factors, including being overweight, alcoholism and gallstone disease $(12,15)$. Given the advanced age of the patient and the absence of earlier attacks or a heredity pattern, it could be speculated that this variation acted as a disease-modifying component by lowering the threshold for development of pancreatitis triggered by other causes, possibly increasing the severity of the clinical course of this disease. Nevertheless, our observation of an extremely low frequency of SPINK1 101A > G prevents any definite conclusion regarding its significance in the disease aetiology and course and does not support routine genotyping in sporadic cases of acute pancreatitis in Serbs.

In conclusion, in Serbian patients diagnosed with acute pancreatitis, PRSS1 $86 \mathrm{~A}>\mathrm{T}$ and $365 \mathrm{G}>\mathrm{A}$ variations were not observed, while SPINK1 101A $>\mathrm{G}$ was present with a frequency of $0.62 \%$. The proposed effect of examined variations on pancreatitis development and severity could not be confirmed. The results do not support routine genotyping of either PRSS1 or SPINK1 in Serbs.

\section{ACKNOWLEDGEMENTS}

The study was financially supported by the Faculty of Medical Sciences, University of Kragujevac, Serbia, JP 10/11, and the Ministry of Science and Technological Development, Republic of Serbia, grants No. 175007 and 175056.

\section{REFERENCES}

1. Karakayali FY. Surgical and interventional management of complications caused by acute pancreatitis. World J Gastroenterol 2014; 20 (37): 13412-13423.

2. Papachristou GI, Clermont G, Sharma A, Yadav D, Whitcomb DC. Risk and markers of severe acute pancreatitis. Gastroenterol Clin North Am 2007; 36 (2): 277-296.

3. Hirota M, Ohmuraya M, Baba H. Genetic background of pancreatitis. Postgrad Med J 2006; 82 (974): 775-778.

4. Wilson PG, Manji M, Neoptolemos JP. Acute pancreatitis as a model of sepsis. Journal of Antimicrobial Chemotherapy 1998; 41, Suppl. A: 51-63.

5. Andersson R, Andersson B, Andersson E, Axelsson J, Eckerwall G, Tingstedt B. Acute pancreatitis--from cellular signalling to complicated clinical course. HPB (Oxford) 2007; 9 (6): 414-420.

6. Beger HG, Rau BM. Severe acute pancreatitis: Clinical course and management. World J Gastroenterol 2007; 13 (38): 5043-5051. 
7. Grendell JH. Genetic factors in pancreatitis. Curr Gastroenterol Rep 2003; 5 (2): 105-109.

8. Rolston RK, Kant JA. Genetic testing in acute and chronic pancreatitis. Curr Gastroenterol Rep 2001; 3 (2): 115-120.

9. Grigorescu M, Grigorescu MD. Genetic factors in pancreatitis. Rom J Gastroenterol 2005; 14 (1): 53-61.

10. Masamune A. Genetics of pancreatitis: the 2014 update. Tohoku J Exp Med 2014; 232 (2): 69-77.

11. Whitcomb DC. Genetic risk factors for pancreatic disorders. Gastroenterology 2013; 144 (6): 1292-1302.

12. Whitcomb DC. Genetic aspects of pancreatitis. Annu Rev Med 2010; 61: 413-424.

13. Whitcomb DC, Gorry MC, Preston RA, et al. Hereditary pancreatitis is caused by a mutation in the cationic trypsinogen gene. Nat Genet 1996; 14: 141-145.

14. Witt H, Luck W, Hennies HC, et al. Mutations in the gene encoding the serine protease inhibitor, Kazal type 1 are associated with chronic pancreatitis. Nat Genet 2000; 25: 213-216.

15. Khan AS, Latif SU, Eloubeidi MA. Controversies in the etiologies of acute pancreatitis. Jop 2010; 11 (6): 545-552.

16. Gomez-Lira M, Bonamini D, Castellani C, et al. Mutations in the SPINK1 gene in idiopathic pancreatitis Italian patients. Eur J Hum Genet 2003; 11 (7): 543-546.

17. Pelaez-Luna M, Robles-Diaz G, Canizales-Quinteros S, Tusie-Luna MT. PRSS1 and SPINK1 mutations in idiopathic chronic and recurrent acute pancreatitis. World J Gastroenterol 2014; 20 (33): 11788-11792.

18. Midha S, Khajuria R, Shastri S, Kabra M, Garg PK. Idiopathic chronic pancreatitis in India: phenotypic characterisation and strong genetic susceptibility due to SPINK1 and CFTR gene mutations. Gut 2010; 59: 800-807.

19. Shimosegawa T, Kume K, Masamune A. SPINK1 gene mutations and pancreatitis in Japan. J Gastroenterol Hepatol 2006; 21 Suppl 3: S47-S51.

20. Cavestro M, Furlloni L, Fontana F, et al. Association of Spink-1 (N34S) and PRSS-1 (N29I and R122H) gene mutations and chronic pancreatitis in Italy. Gastroenterol 2003; 124 suppl 1: A-585.

21. Applebaum-Shapiro SE, Finch R, Pfützer RH, et al. Hereditary pancreatitis in North America: the PittsburghMidwest Multi-Center Pancreatic Study Group Study. Pancreatology 2001; 1: 439-443.

22. Bernardino AL, Guarita DR, Mott CB, et al. CFTR, PRSS1 and SPINK1 mutations in the development of pancreatitis in Brazilian patients. Jop 2003; 4 (5): 169-177.

23. Bradley EL. A clinically based classification system for acute pancreatitis. Ann Chir 1993; 47: 527-541.

24. Masamune A, Ariga H, Kume K, et al. Genetic background is different between sentinel and recurrent acute pancreatitis. J Gastroenterol Hepatol 2011; 26 (6): 974-978.

25. Mora J, Comas L, Ripoll E, et al. Genetic mutations in a Spanish population with chronic pancreatitis. Pancreatology 2009; 9: 644-651.
26. Papachristou GI, Whitcomb D. Predictors of severity and necrosis in acute pancreatitis. Gastroenterol Clin N Am 2004; 33: 871-890.

27. Whitcomb D, Preston RA, Aston CE. A gene for hereditary pancreatitis maps to chromosome 7q35. Gastroenterol 1996; 110: 1975-1980.

28. Gorry MC, Gabbaizedeh D, Furey W. Mutations in the cationic trypsinogen gene are associated with recurrent acute and chronic pancreatitis. Gastroenterology 1997; 113: 1063-1068.

29. Whitcomb D. Genetic predispositions to acute and chronic pancreatitis. Medical Clinics of North America 2000; 84 (3): DOI: 10.1016/S0025-7125\%2805\%29702382970238.

30. Sahin-Toth M. Biochemical models of hereditary pancreatitis. Endocrinol Metab Clin North Am 2006; 35 (2): 303-312, ix.

31. Pfutzer RH, Barmada MM, Brunskill APJ, et al. SPINK1/PSTI polymorphisms act as disease modifiers in familial and idiopathic chronic pancreatitis. Gastroenterology 2000; 119: 615-623.

32. Chandak GR, Idris MM, Reddy DN, Bhaskar S, Sriram PV, Singh L. Mutations in the pancreatic secretory trypsin inhibitor gene (PSTI/SPINK1) rather than the cationic trypsinogen gene (PRSS1) are significantly associated with tropical calcific pancreatitis. J Med Genet 2002; 39 (5): 347-351.

33. Nishimori I, Kamakura M, Fujikawa-Adachi K, et al. Mutations in exons 2 and 3 of the cationic trypsinogen gene in Japanese families with hereditary pancreatitis. Gut 1999; 44 (2): 259-263.

34. O’Reilly DA, Kingsnorth AN. Hereditary pancreatitis and mutations of the cationic trypsinogen gene. Br J Surg 2000; 87 (6): 708-717.

35 . Whitcomb DC. Value of genetic testing in the management of pancreatitis. Gut 2004; 53 (11): 1710-1717.

36. LaRusch J, Whitcomb DC. Genetics of pancreatitis. Curr Opin Gastroenterol 2011; 27 (5): 467-474.

37. Chandak GR, Idris MM, Reddy DN, et al. Absence of PRSS1 mutations and association of SPINK1 trypsin inhibitor mutations in hereditary and non-hereditary chronic pancreatitis. Gut 2004; 53 (5): 723-728.

38. Audrezet MP, Chen JM, Le Marechal C, et al. Determination of the relative contribution of three genes-the cystic fibrosis transmembrane conductance regulator gene, the cationic trypsinogen gene, and the pancreatic secretory trypsin inhibitor gene-to the etiology of idiopathic chronic pancreatitis. Eur J Hum Genet 2002; 10 (2): 100-106.

39. Drenth JP, te Morsche R, Jansen JB. Mutations in serine protease inhibitor Kazal type 1 are strongly associated with chronic pancreatitis. Gut 2002; 50 (5): 687-692.

40. Perri F, Piepoli A, Andriulli A. On the role of CFTR, PSSR1 and PST1/SPINK1 in idiopathic chronic pancreatitis. Eur J Hum Genet 2003; 11 (2): 107; author reply 108. 
41. Joergensen MT, Brusgaard K, Cruger DG, Gerdes AM, de Muckadell OBS. Genetic, epidemiological, and clinical aspects of hereditary pancreatitis: a populationbased cohort study in Denmark. Am J Gastroenterol 2010; 105: 1876-1883.

42. Gasiorowska A, Talar-Wojnarowska R, Czupryniak L, et al. The prevalence of cationic trypsinogen (PRSS1) and serine protease inhibitor, Kazal type 1 (SPINK1) gene mutations in Polish patients with alcoholic and idiopathic chronic pancreatitis. Dig Dis Sci 2011; 56 (3): 894-901.

43. Masson E, Chen JM, Audrezet MP, Cooper DN, Ferec $\mathrm{C}$. A conservative assessment of the major genetic causes of idiopathic chronic pancreatitis: data from a comprehensive analysis of PRSS1, SPINK1, CTRC and CFTR genes in 253 young French patients. PLoS One 2013; 8 (8): e73522.

44. Wang W, Sun XT, Weng XL, et al. Comprehensive screening for PRSS1, SPINK1, CFTR, CTRC and CLDN2 gene mutations in Chinese paediatric patients with idiopathic chronic pancreatitis: a cohort study. BMJ Open 2013; 3 (9): e003150.

45. Keim V, Bauer N, Teich N, Simon P, Lerch MM, Mossner J. Clinical characterization of patients with hereditary pancreatitis and mutations in the cationic trypsinogen gene. Am J Med 2001; 111 (8): 622-626.

46. O’Reilly DA, Yang BM, Creighton JE, Demaine AG, Kingsnorth AN. Mutations of the cationic trypsinogen gene in hereditary and non-hereditary pancreatitis. Digestion 2001; 64: 54-60.

47. Chen JM, Mercier B, Audrezet MP, Ferec C. Mutational analysis of the human pancreatic secretory trypsin inhibitor (PSTI) gene in hereditary and sporadic chronic pancreatitis. J Med Genet 2000; 37 (1): 67-69.

48. Treiber M, Schlag C, Schmid RM. Genetics of pancreatitis: a guide for clinicians. Current Gastroenterology Reports 2008; 10: 122-127.

49. Wang GP, Xu CS. Pancreatic secretory trypsin inhibitor: More than a trypsin inhibitor. World J Gastrointest Pathophysiol 2010; 1 (2): 85-90.
50. Ohmuraya M, Yamamura K. Roles of serine protease inhibitor Kazal type 1 (SPINK1) in pancreatic diseases. Exp Anim 2011; 60 (5): 433-444.

51. Horii A, Kobayashi T, Tomita N, et al. Primary structure of human pancreatic secretory trypsin inhibitor (PSTI) gene. Biochem. Biophys. Res. Commun 1987; 149: 635-641.

52. Aoun E, Chang CC, Greer JB, Papachristou GI, Barmada MM, Whitcomb DC. Pathways to injury in chronic pancreatitis: decoding the role of the high-risk SPINK1 N34S haplotype using meta-analysis. PLoS One 2008; 3 (4): e2003.

53. Threadgold J, Greenhalf W, Ellis I, et al. The N34S mutation of SPINK1 (PSTI) is associated with a familial pattern of idiopathic chronic pancreatitis but does not cause the disease. Gut 2002; 50 (5): 675-681.

54. Cavestro GM, Zuppardo RA, Bertolini S, et al. Connections between genetics and clinical data: role of MCP-1, CFTR, and SPINK-1 in the setting of acute, acute recurrent, and chronic pancreatitis. Am J Gastroenterol 2010; 105: 199-206.

55. Schneider A, Larusch J, Sun X, et al. Combined bicarbonate conductance-impairing variants in CFTR and SPINK1 variants are associated with chronic pancreatitis in patients without cystic fibrosis. Gastroenterology 2010; 140 (1): 162-171.

56. Hirota M, Kuwata K, Ohmuraya M, Ogawa M. From acute to chronic pancreatitis: the role of mutations in the pancreatic secretory trypsin inhibitor gene. Jop 2003; 4 (2): 83-88.

57. Ockenga J, Dork T, Stuhrmann M. Low prevalence of SPINK1 gene mutations in adult patients with chronic idiopathic pancreatitis. J Med Genet 2001; 38 (4): 243-244.

58. Diaconu BL, Ciobanu L, Mocan T, et al. Investigation of the SPINK1 N34S mutation in Romanian patients with alcoholic chronic pancreatitis. A clinical analysis based on the criteria of the M-ANNHEIM classification. J Gastrointestin Liver Dis 2009; 18 (2): 143-150.

59. Witt H. The SPINK in chronic pancreatitis: similar finds, different minds. Gut 2002; 50: 590-591. 